\title{
Effect of Pectin and Amidated Pectin on Cholesterol Homeostasis and Cecal Metabolism in Rats Fed a High- Cholesterol Diet
}

\author{
M. MAROUNEK ${ }^{1,2}$, Z. VOLEK ${ }^{1}$, A. SYNYTSYA ${ }^{3}$, J. ČOPÍKOVÁ $^{3}$ \\ ${ }^{1}$ Research Institute of Animal Production, ${ }^{2}$ Institute of Animal Physiology and Genetics, Academy \\ of Sciences of the Czech Republic, ${ }^{3}$ Department of Carbohydrate Chemistry and Technology, \\ Institute of Chemical Technology, Prague, Czech Republic
}

Received February 16, 2006

Accepted July 14, 2006

On-line available August 22, 2006

\begin{abstract}
Summary
Two experiments were performed to compare the effect of pectin and its hydrophobic derivatives on homeostasis of cholesterol and cecal metabolism in male young rats. Control rats were fed a diet supplemented with palm fat and cholesterol (50 and $10 \mathrm{~g} / \mathrm{kg}$, respectively). Rats of other groups were fed the same diet containing citrus pectin or octadecylpectinamide $(60 \mathrm{~g} / \mathrm{kg})$. Diets were fed for 4 weeks. In experiment I, pectinamide of lower degree of amidation (30\%) increased serum HDL cholesterol from 1.20 to $1.43 \mu \mathrm{mol} / \mathrm{ml}(\mathrm{p}>0.05)$ at the expense of other cholesterol fractions. In experiment II, pectinamide of a higher degree of amidation (53\%) significantly decreased total serum cholesterol from 2.08 to $1.67 \mu \mathrm{mol} / \mathrm{ml}$. Amidated pectins at both levels of substitution significantly decreased hepatic concentrations of cholesterol and fat. In both experiments the relative weight of cecum in the pectinamide group was significantly lower than in pectin group. The highest cecal concentrations of short-chain fatty acids (SCFA) were found in rats fed a diet with pectin (133.2 and $129.3 \mu \mathrm{mol} / \mathrm{g}$ in experiment I and II, respectively). In other groups, cecal SCFA was significantly (pectinamide groups) or non-significantly (controls) lower. In wet feces, SCFA concentrations were higher and butyrate molar proportions lower than in corresponding cecal contents. Pectinamide of a lower or higher degree of substitution significantly increased fecal content of cholesterol from 18.5 and $17.3 \mu \mathrm{mol} / \mathrm{g}$ in controls to 31.8 and $28.0 \mu \mathrm{mol} / \mathrm{g}$, respectively. Corresponding concentrations of coprostanol were decreased. Effects of pectin on cholesterol homeostasis were absent or marginal. Histological examination revealed that hepatic tissue of control and pectin-fed rats was infiltrated with lipids. The Sudan black-positive material was absent in the liver of rats fed pectinamides. No pathological changes of liver tissue were apparent. In summary, hydrophobic amidated pectins significantly altered cholesterol homeostasis in rats and might be considered as a clinically effective hypocholesterolemic agent. Low cecal SCFA concentrations in rats fed pectinamides suggest that amidation of pectin had decreased its fermentability.
\end{abstract}

Key words

Pectin $\bullet$ Amidated pectins $\bullet$ Rat $\bullet$ Cholesterol $\bullet$ Feces 


\section{Introduction}

Pectin is a polymer of galacturonic acid linked by $\alpha-1-4$ bonds and methoxylated to a varying extent at the carboxyl moieties. Other sugars, acetyl groups and calcium ions are present as additional constituents (Aspinall 1970). In the human diet, pectin occurs as a "soluble fiber" in fruit and vegetables, jams and jellies, and more recently in low-calorie foods as a fat replacer (Thakur et al. 1997). In the small intestine, pectin and other gel-forming polysaccharides increase viscosity and affect the process of digestion and absorption. Physiological effects of pectin include a reduction in plasma and liver cholesterol concentration in rats (Judd and Truswell 1985, Arjmandi et al. 1992, Hexeberg et al. 1994), hamsters (Terpstra et al. 1998, 2002) and guinea pigs (Fernandez 1995, Fernandez et al. 1994). In pectinfed animals, a decrease of ileal digestibility of organic mater and protein (Mosenthin et al. 1994) and increase of fecal excretion of nitrogen (Pastuszewska et al. 2000a) were observed. Pectin passes the small intestine as a macromolecule (Dongowski et al. 2002). In humans, approximately $90 \%$ of ingested pectin was recovered in the terminal ileum (Saito et al. 2005). In the lower intestinal tract pectin is fermented to short-chain fatty acids (Bourquin et al. 1996). Individual short-chain fatty acids (SCFA) differ in their physiological significance for the host. Acetate is the respiratory fuel and a precursor for lipogenesis and cholesterolgenesis. Propionate is gluconeogenic and a precursor of amino acids. In rats, intracecal infusions of propionic acid decreased plasma cholesterol, but total lipids and cholesterol in the liver were not affected (Ebihara et al. 1993). Butyrate is the respiratory fuel for enterocytes. When pectin was present in the diet of rats, the acetate concentration in cecal contents was increased and that of butyrate decreased (Thomsen et al. 1984).

Sequestrants of bile acids and neutral sterols disturb cholesterol homeostasis in humans and in different experimental animals. Psyllium (a food additive) and cholestyramine (a pharmacological agent) increase fecal excretion of steroids, and consequently decrease hepatic and serum concentrations of cholesterol (Trautwein et al. 1998, Van Bennekum et al. 2005). This mode of action seems to be more efficient as mere increasing of intestinal viscosity leads to greater excretion of neutral steroids, but not of bile acids (Carr et al. 2003). Amidated pectins are amphiphilic polymers with a polar backbone (galacturonic units of pectin) and non-polar alkyl substituents. The hydrophilicity-lipophilicity relationship of such polymers depends on the degree of substitution. A higher degree of substitution with nonpolar groups leads to total insolubility in water (Synytsya et al. 2004). Amidated pectins have a potential value as drug carriers (Wakerly et al. 1997) and sorbents for removing non-polar compounds from water (Synytsya et al. 2004). Preliminary in vitro experiments showed that amidated pectins were efficient sorbents of cholesterol and bile acids (Synytsya et al. 2005). Hence, experiments were performed to assess the effects of these novel substances on serum and hepatic cholesterol, cecal metabolism and growth of rats fed a high-cholesterol diet.

\section{Methods}

\section{Pectin and pectinamides}

A highly methoxylated (73\%) citrus pectin type XSS was supplied by Danisco Cultor Bohemia (Smiřice, Czech Republic). N-octadecylpectinamides with degrees of substitution of 30 and $53 \%$ were prepared by heterogenous amino-dealkoxylation of this pectin with n-octadecylamide as described by Synytsya et al. (2004). The degrees of amidation were calculated from results of organic elemental analysis.

\section{Animals and diets}

Two experiments were performed on two sets of 21 male Wistar rats aged about 6 weeks. Rats were housed individually in a temperature- and humiditycontrolled room. Environmental conditions were as follows: temperature $22 \pm 1{ }^{\circ} \mathrm{C}$, relative humidity $55 \%$, 12h light: $12 \mathrm{~h}$ dark daily photoperiod cycle. Rats were fed a standard rat diet ST-1 (Velaz Ltd., Lysolaje, Czech Republic). Chemical composition and ingredients of the diet are shown in Table 1. After one week, rats were randomly divided into three groups of seven animals: the first group (control) was fed the ST-1 diet supplied with protected palm fat (Megalac $^{\mathrm{TM}}$, Agro-Best Ltd., Běstovice, Czech Republic) and cholesterol (Sigma) at 50 and $10 \mathrm{~g} / \mathrm{kg}$, respectively. The other two groups were fed the same high-cholesterol diet containing $60 \mathrm{~g} / \mathrm{kg}$ of either citrus pectin or its amidated derivative. Food and water were available ad libitum. In the first experiment, octadecylpectinamide with a lower degree of substitution (30\%) was used. Octadecylpectinamide with degree of substitution of $53 \%$ was added into the diet of rats in the second experiment. Both experiments lasted for four weeks. Food intake and water consumption was measured daily. Rats were weighed once a week. 
Table 1. Chemical composition of standard rat diet ST-1 (per kg)

\begin{tabular}{lc} 
Crude protein & $240 \mathrm{~g}$ \\
Crude fibre & $44 \mathrm{~g}$ \\
Fat & $34 \mathrm{~g}$ \\
Ash & $68 \mathrm{~g}$ \\
$\mathrm{Ca}$ & $10 \mathrm{~g}$ \\
$\mathrm{P}$ & $7.2 \mathrm{~g}$ \\
$\mathrm{Na}$ & $1.8 \mathrm{~g}$ \\
$\mathrm{Cu}$ & $20 \mathrm{mg}$ \\
$\mathrm{Se}$ & $0.38 \mathrm{mg}$ \\
L-lysine & $14 \mathrm{~g}$ \\
D, L-methionine & $4.8 \mathrm{~g}$ \\
Vitamin A & $28000 \mathrm{IU}$ \\
Vitamin $D_{3}$ & $2200 \mathrm{IU}$ \\
Vitamin E & $100 \mathrm{mg}$ \\
\hline
\end{tabular}

a Diet ST-1 ingredients were soyabean meal (extracted), fish meal, wheat, maize, oat, wheat meal, wheat bran, limestone, dicalcium phosphate, salt and supplements of vitamins, trace elements and amino acids. Experimental diets were supplemented with palm fat and cholesterol at 50 and $10 \mathrm{~g} / \mathrm{kg}$, respectively. Pectin and amidated pectins were added at $60 \mathrm{~g} / \mathrm{kg}$.

\section{Sampling}

Feces were collected daily during the last week of the experiment, pooled and kept at $-40{ }^{\circ} \mathrm{C}$ until analyzed. At the end of the 4-week feeding period, animals were sacrificed by means of a T-61 preparation (Intervet International GmbH, Germany). Samples of blood were withdrawn to obtain the serum. After laparotomy, the ceca, livers and spleens were excised and weighed. The ceca were emptied by squeezing, cecal contents weighed, diluted 1:2 with distilled water, and frozen. Livers were halved and one half fixed in buffered neutral formaldehyde (Pearse 1968) for histochemical examination. The second half was frozen and kept at $-40{ }^{\circ} \mathrm{C}$ until analyzed.

\section{Analyses}

Serum triacylglycerol concentrations, total cholesterol and its fractions were determined enzymatically using a Roche Hitachi 912 clinical chemistry system and kits supplied by BioVendor, Inc. (Brno, Czech Republic). Total lipids were extracted from livers and feces with 2:1 chloroform-methanol (Folch et al. 1957). Lipids in the extracts were determined gravimetrically, after washing with $1 \% \mathrm{NaCl}$ and $50 \%$ methanol solutions. In order to determine cholesterol and coprostanol, lipids were saponified and the unsaponified matter extracted with diethyl ether according to ISO 3596-1 (1988). Silyl derivates were prepared using TMCS and HMDS silylation reagents (Sigma-Aldrich) and quantified on a gas chromatograph equipped with a SAC-5 capillary column (Supelco) operated isothermally at $285{ }^{\circ} \mathrm{C}$. Total SCFA in diluted cecal contents were determined by titration after steam distillation. Fecal samples were homogenized in water (1:3) and filtered through a sieve with $1 \mathrm{~mm}$ openings. Total SCFA were determined in the filtrate by titration after steam distillation. The SCFA molar percentages were estimated by gas chromatography at $140^{\circ} \mathrm{C}$, employing a column of the Chromosorb WAW with $15 \%$ SP 1220 and $1 \%$ $\mathrm{H}_{3} \mathrm{PO}_{4}$ (Supelco). Ammonia was determined colorimetrically with Nessler reagent after prior separation from interfering compounds by microdiffusion in Conway units (Conway 1957).

Sections of liver tissue $(10 \mu \mathrm{m}$ thick) were cut using a freezing microtome Mikrotom M3 (Medexport, Moscow, Russia) and stained with diazo dye Sudan black $\mathrm{B}$ for the demonstration of lipids. In order to detect possible pathomorphological changes, standard hematoxylin-stained paraffin sections were prepared. To ensure the comparability between different groups, all sections were stained in one batch. Sections were examined microscopically using a microscope equipped with an Olympus digital camera.

Data were statistically analyzed by one-way analysis of variance using the GLM procedure of SAS, version 8.2 (SAS Institute, Cary, NC, U.S.A.). In the case of a significant difference $(\mathrm{p}<0.05)$, groups were compared by Tukey's test.

\section{Results}

Rats fed pectin and amidated pectins gained less weight than control rats. Compared to the controls, pectin and pectinamides significantly decreased body weight gain by $14 \mathrm{~g}$ and $10 \mathrm{~g}$, and by $12 \mathrm{~g}$ and $20 \mathrm{~g}$ in experiment I and II, respectively (Table 2). There were no differences in food intake, so that food conversion, i.e. food consumed per $1 \mathrm{~g}$ of gain, was better in control rats than in those fed pectins. In experiment I, weight of the liver in rats consuming pectinamide of a lower degree of substitution was significantly lower than in control rats. Serum triacylglycerols did not differ significantly among treatments (Table 3). Compared to the control group, no significant effect of pectin on serum cholesterol, HDL cholesterol and non-HDL cholesterol was observed. 
Table 2. Effect of pectin and amidated pectins on growth, food intake and weight of spleen and liver in rats fed a high-cholesterol diet.

\begin{tabular}{|c|c|c|c|c|c|c|}
\hline & \multicolumn{3}{|c|}{ Experiment I } & \multicolumn{3}{|c|}{ Experiment II } \\
\hline & Control & Pectin & $\begin{array}{c}\text { Pectinamide } \\
\text { (30\%) }\end{array}$ & Control & Pectin & $\begin{array}{c}\text { Pectinamide } \\
(53 \%)\end{array}$ \\
\hline $\begin{array}{l}\text { Initial weight } \\
(g)\end{array}$ & $180 \pm 8$ & $180 \pm 9$ & $181 \pm 6$ & $174 \pm 6$ & $172 \pm 10$ & $172 \pm 8$ \\
\hline $\begin{array}{l}\text { Final weight } \\
(g)\end{array}$ & $298 \pm 10$ & $284 \pm 9$ & $289 \pm 13$ & $294 \pm 10$ & $280 \pm 10 *$ & $272 \pm 9 *$ \\
\hline $\begin{array}{l}\text { Weight gain } \\
\text { (g) }\end{array}$ & $118 \pm 5$ & $104 \pm 5 *$ & $108 \pm 10 *$ & $120 \pm 10$ & $108 \pm 8 *$ & $100 \pm 7 *$ \\
\hline $\begin{array}{l}\text { Food intake } \\
\text { (g/day) }\end{array}$ & $20.9 \pm 0.5$ & $20.9 \pm 0.7$ & $21.6 \pm 0.3$ & $20.2 \pm 0.8$ & $20.0 \pm 0.5$ & $20.3 \pm 0.7$ \\
\hline $\begin{array}{l}\text { Food conversion } \\
(\mathrm{g} / \mathrm{g})\end{array}$ & $4.96 \pm 0.24$ & $5.52 \pm 0.41 *$ & $5.60 \pm 0.40 *$ & $4.71 \pm 0.31$ & $5.19 \pm 0.37 *$ & $5.68 \pm 0.35 * \#$ \\
\hline $\begin{array}{l}\text { Water intake } \\
\text { (ml/day) }\end{array}$ & $54.3 \pm 4.6$ & $53.8 \pm 4.2$ & $55.4 \pm 3.7$ & $46.1 \pm 2.2$ & $59.0 \pm 8.0 *$ & $55.0 \pm 6.6 *$ \\
\hline $\begin{array}{l}\text { Weight of spleen } \\
(\% \text { of body wt) }\end{array}$ & $0.22 \pm 0.03$ & $0.24 \pm 0.04$ & $0.24 \pm 0.02$ & $0.23 \pm 0.05$ & $0.25 \pm 0.04$ & $0.28 \pm 0.03$ \\
\hline $\begin{array}{l}\text { Weight of liver } \\
(\% \text { of body wt) }\end{array}$ & $4.32 \pm 0.29$ & $4.10 \pm 0.32$ & $3.78 \pm 0.27 *$ & $3.91 \pm 0.14$ & $3.88 \pm 0.24$ & $3.69 \pm 0.26$ \\
\hline
\end{tabular}

Data are mean values \pm S.D. Significant differences $(p<0.05): *$ from controls, ${ }^{*}$ from pectin.

Table 3. Effect of pectin and amidated pectins on serum concentrations of triacylglycerols, cholesterol and cholesterol fractions, and hepatic concentration of fat, cholesterol and coprostanol in rats fed a high-cholesterol diet.

\begin{tabular}{|c|c|c|c|c|c|}
\hline \multicolumn{3}{|c|}{ Experiment I } & \multicolumn{3}{|c|}{ Experiment II } \\
\hline Control & Pectin & $\begin{array}{c}\text { Pectinamide } \\
(\mathbf{3 0} \%)\end{array}$ & Control & Pectin & $\begin{array}{c}\text { Pectinamide } \\
(53 \%)\end{array}$ \\
\hline
\end{tabular}

\begin{tabular}{|c|c|c|c|c|c|c|}
\hline \multicolumn{7}{|l|}{ Serum concentrations } \\
\hline $\begin{array}{l}\text { Triacylglycerols } \\
(\mathrm{mmol} / \mathrm{l})\end{array}$ & $1.97 \pm 0.64$ & $2.13 \pm 0.62$ & $1.53 \pm 0.58$ & $1.40 \pm 0.54$ & $1.36 \pm 0.75$ & $1.58 \pm 0.48$ \\
\hline $\begin{array}{l}\text { Total cholesterol } \\
(\mathrm{mmol} / \mathrm{l})\end{array}$ & $1.99 \pm 0.15$ & $1.94 \pm 0.15$ & $1.96 \pm 0.19$ & $2.08 \pm 0.36$ & $2.06 \pm 0.25$ & $1.67 \pm 0.21 *^{\#}$ \\
\hline $\begin{array}{l}\text { HDL cholesterol } \\
(\mathrm{mmol} / \mathrm{l})\end{array}$ & $1.20 \pm 0.14$ & $1.14 \pm 0.22$ & $1.43 \pm 0.14^{\#}$ & $1.19 \pm 0.20$ & $1.17 \pm 0.20$ & $1.20 \pm 0.18$ \\
\hline $\begin{array}{l}\text { HDL cholesterol } \\
\text { (\% of total) }\end{array}$ & $60.2 \pm 5.0$ & $59.2 \pm 11.7$ & $73.3 \pm 9.2 *^{\#}$ & $57.3 \pm 4.4$ & $56.9 \pm 7.1$ & $71.8 \pm 2.2 *^{\#}$ \\
\hline $\begin{array}{l}\text { Non-HDL cholesterol } \\
(\mathrm{mmol} / \mathrm{l})\end{array}$ & $0.79 \pm 0.11$ & $0.80 \pm 0.25$ & $0.53 \pm 0.18 * \#$ & $0.89 \pm 0.19$ & $0.89 \pm 0.20$ & $0.47 \pm 0.03 * \#$ \\
\hline \multicolumn{7}{|l|}{ Hepatic concentrations } \\
\hline Fat $(m g / g)$ & $54.9 \pm 7.5$ & $57.7 \pm 6.9$ & $45.3 \pm 3.0 * \#$ & $60.3 \pm 7.1$ & $55.0 \pm 7.0$ & $46.4 \pm 2.8 *^{\#}$ \\
\hline Cholesterol ( $\mu \mathrm{mol} / \mathrm{g})$ & $12.9 \pm 3.0$ & $15.6 \pm 5.4$ & $5.7 \pm 0.6 * \#$ & $15.0 \pm 3.9$ & $12.2 \pm 2.9$ & $5.6 \pm 0.5 *^{\#}$ \\
\hline Coprostanol (nmol/g) & $16.5 \pm 12.1$ & $63.8 \pm 28.8$ & $52.6 \pm 81.3$ & $29.8 \pm 8.7$ & $92.9 \pm 87.2$ & $12.9 \pm 18.5^{\#}$ \\
\hline
\end{tabular}

Data are mean values \pm S.D. Significant differences $(\mathrm{p}<0.05): *$ from controls, ${ }^{\#}$ from pectin. 
Both pectinamides significantly increased the proportion of HDL-cholesterol at the expense of other cholesterol fractions. Pectinamide with a higher degree of amidation significantly decreased cholesterolemia from 2.08 to1.67 $\mu \mathrm{mol} / \mathrm{ml}$ without affecting HDL-cholesterol levels. There was no significant effect of dietary pectin on hepatic concentrations of fat and cholesterol. In contrast, amidated pectins significantly decreased hepatic concentration of fat from 54.9 and $60.3 \mathrm{mg} / \mathrm{g}$ to 45.3 and $46.4 \mathrm{mg} / \mathrm{g}$ in experiment I and II, respectively. Both pectinamides significantly decreased hepatic concentrations of cholesterol from 12.9 and $15.0 \mu \mathrm{mol} / \mathrm{g}$ to 5.7 and 5.6 $\mu \mathrm{mol} / \mathrm{g}$ in experiment I and II, respectively. Liver tissue contained traces of coprostanol.

Figures 1A, 1C, 1E and $1 \mathrm{G}$ present the morphology of the hepatic tissue stained with hematoxylin using a standard paraffin technique. Figures 1B, 1D, 1F and $1 \mathrm{H}$ present the appearance of hepatic tissue stained with the fat-soluble dye Sudan black B. Figures $1 B$ and 1D show that hepatic tissue of rats fed a control diet or a diet with pectin, respectively, was strongly infiltrated with lipids (steatosis), which stain black with Sudan black B. The Sudan black-positive material was absent in livers of rats fed pectinamides (Figs $1 \mathrm{~F}$ and $1 \mathrm{H}$ ). There were no differences in the appearance of hematoxylin-stained samples of liver tissue in rats fed the different diets. No pathological changes of liver tissue were apparent.

An enlargement of the cecum was observed in rats fed pectin (Table 4). In parallel, there was also an increase in the cecal content and cecal wall weight.

The fermentation pattern differed in the cecum of pectin- and pectinamide-fed rats. The proportion of acetate was significantly higher in the former animals and that of butyrate was higher in the latter ones. Other SCFA, i.e. isobutyrate, valerate, isovalerate and caproate, accounted for 5.4-12.9\% of the total SCFA. Their concentrations were higher in the amidated pectin groups. The fecal SCFA concentrations were higher by 31-60 $\mu \mathrm{mol} / \mathrm{g}$ than corresponding SCFA concentrations in the cecum (Table 5).

The digesta passage through the colon remarkably changed the SCFA composition: acetate molar percentage increased and that of butyrate decreased approximately to one half. The feces of rats fed pectin contained less dry matter than feces of other rats, but the difference was not significant. Feces of rats fed amidated pectins did not contain significantly more fat than feces of control rats and significantly more cholesterol and less coprostanol than the feces of other rats.
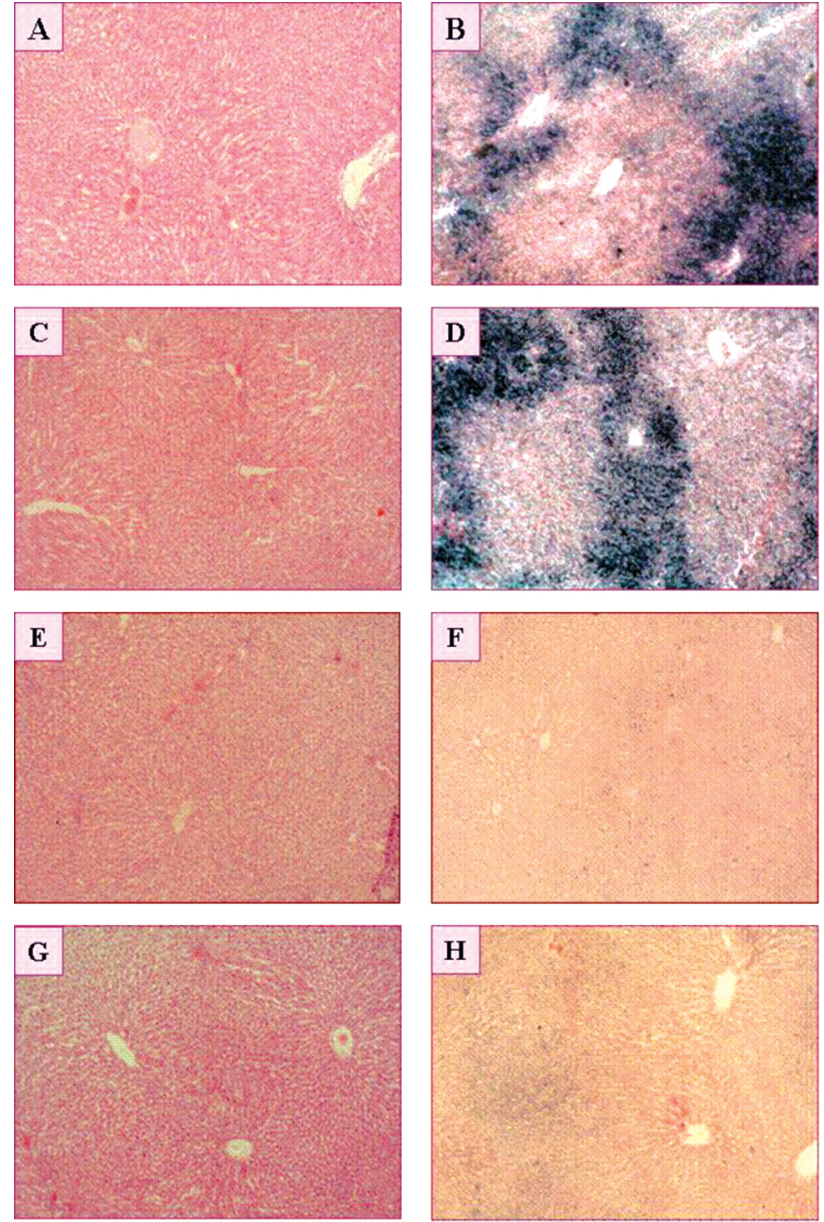

Fig. 1. Histological analysis of liver tissue of rats fed a control diet $(A, B)$ or a diet supplemented with pectin $(C, D)$, or a diet with pectinamid of lower $(E, F)$ or higher degree of substitution $(G, H)$. Sections of liver tissue were stained with hematoxylin $(A$, C, E, G) or Sudan black B dye (B, D, F, H). Magnification x 25 .

\section{Discussion}

Amidation of pectin offers an opportunity to compare physiological effects of soluble and insoluble fibers with the same carbohydrate backbone. Neither pectin nor amidated pectins influenced food intake. The gain in body weight, however, was significantly lower in rats fed pectins, probably due to a lower yield of energy in utilization of these substrates. There were no signs of toxicity of amidated pectins. No pathological changes of liver tissue were observed. Serum triacylglycerols and cholesterol concentrations were within the reference range of values reported for young male rats (Wolford et al. 1986). Rats have the ability to convert dietary cholesterol to bile acids (Horton et al. 1995), so that they are resistant to hypercholesterolemic diets. Bile acids concentrations in the feces was not measured in the present study. However, octadecylpectinamide with the 
Table 4. Effect of pectin and amidated pectins on weight of cecum and parameters of cecal metabolism in rats fed a high-cholesterol diet

\begin{tabular}{|c|c|c|c|c|c|c|}
\hline & \multicolumn{3}{|c|}{ Experiment I } & \multicolumn{3}{|c|}{ Experiment II } \\
\hline & Control & Pectin & $\begin{array}{c}\text { Pectinamide } \\
(30 \%)\end{array}$ & Control & Pectin & $\begin{array}{c}\text { Pectinamide } \\
(53 \%)\end{array}$ \\
\hline \multicolumn{7}{|c|}{ Weight (\% of body wt) } \\
\hline Cесum & $2.66 \pm 0.24$ & $3.02 \pm 0.45$ & $2.38 \pm 0.32^{\#}$ & $2.47 \pm 0.25$ & $3.01 \pm 0.49 *$ & $2.39 \pm 0.26^{\#}$ \\
\hline Cecal content & $2.11 \pm 0.22$ & $2.31 \pm 0.49$ & $1.88 \pm 0.32$ & $1.70 \pm 0.22$ & $1.95 \pm 0.44$ & $1.59 \pm 0.26$ \\
\hline Cecal wall & $0.72 \pm 0.04$ & $0.76 \pm 0.07$ & $0.68 \pm 0.04^{\#}$ & $0.77 \pm 0.09$ & $1.06 \pm 0.19 *$ & $0.80 \pm 0.10^{\#}$ \\
\hline \multicolumn{7}{|l|}{ Cecal metabolites } \\
\hline $\begin{array}{l}\text { Total SCFA } \\
(\mu \mathrm{mol} / \mathrm{g})\end{array}$ & $123.2 \pm 6.5$ & $133.2 \pm 9.1$ & $114.0 \pm 10.8^{\#}$ & $105.1 \pm 21.6$ & $129.3 \pm 27.5$ & $91.5 \pm 16.0^{\#}$ \\
\hline $\begin{array}{l}\text { Acetate } \\
(\text { mol. \%) }\end{array}$ & $55.1 \pm 3.5$ & $62.1 \pm 4.5 *$ & $54.7 \pm 5.8^{\#}$ & $53.8 \pm 1.5$ & $55.5 \pm 4.6$ & $44.8 \pm 2.3 * \#$ \\
\hline $\begin{array}{l}\text { Propionate } \\
\text { (mol. \%) }\end{array}$ & $10.3 \pm 2.1$ & $9.0 \pm 0.4$ & $10.4 \pm 1.2$ & $12.5 \pm 1.7$ & $11.6 \pm 0.9$ & $12.0 \pm 2.1$ \\
\hline $\begin{array}{l}\text { Butyrate } \\
\text { (mol. \%) }\end{array}$ & $28.5 \pm 4.2$ & $23.5 \pm 3.1$ & $27.8 \pm 4.2$ & $22.8 \pm 3.1$ & $24.2 \pm 3.4$ & $30.3 \pm 5.5 * \#$ \\
\hline $\begin{array}{l}\text { Other SCFA } \\
(\text { mol. } \%)\end{array}$ & $6.1 \pm 1.2$ & $5.4 \pm 1.0$ & $7.1 \pm 1.2^{\#}$ & $10.9 \pm 2.6$ & $8.7 \pm 1.7$ & $12.9 \pm 1.7^{\#}$ \\
\hline $\begin{array}{l}\text { Ammonia } \\
(\mu \mathrm{mol} / \mathrm{g})\end{array}$ & $8.1 \pm 1.5$ & $10.4 \pm 2.1$ & $9.3 \pm 2.4$ & $7.6 \pm 1.8$ & $6.5 \pm 0.8$ & $6.2 \pm 0.6$ \\
\hline
\end{tabular}

Data are mean values \pm S.D. Significant differences $(p<0.05): *$ from controls, ${ }^{*}$ from pectin.

degree of substitution of $45 \%$ adsorbed cholic acid under in vitro conditions (Synytsya et al. 2005), thus we suppose that a similar interaction exists in vivo as well. As observed in other studies, HDL-cholesterol was the principal fraction of serum cholesterol in rats (Han et al. 2003). Amidated pectins significantly influenced cholesterol homeostasis in rats. Both pectinamides decreased the concentration of non-HDL-cholesterol in the serum and increased the ratio of HDL-cholesterol to total cholesterol. Pectinamides decreased the concentration of cholesterol in livers and increased its concentration in feces. More hydrophobic pectin derivative significantly decreased cholesterolemia. The same effects were observed in mice fed a diet supplemented with cholestyramine, which is a styrenedivinylbenzene copolymer containing quarternary ammonium groups (Van Bennekum et al. 2005). The liver tissue contained very small but measurable amounts of coprostanol, probably as a consequence of coprophagy. In several studies on rats, cholesterol concentrations in the liver varied from $1 \mathrm{mg} / \mathrm{g}$ (Han et al. 2003) to $72 \mathrm{mg} / \mathrm{g}$ (Van Bennekum et al. 2005). Values found in our study
(12.9 and $15.0 \mu \mathrm{mol} / \mathrm{g}$, i.e. 5.0 and $5.8 \mathrm{mg} / \mathrm{g}$ in control rats) were similar to those reported by Gallaher et al. (2000). The effect of pectinamides on histological data was more pronounced than on liver concentrations of fat, probably due to a different affinity of Sudan black B dye to infiltrated fat and structural lipids.

In both experiments, pectin increased the cecum weight and cecal concentration of SCFA. The cecum enlargement was observed in pectin-fed rats (Thomsen et al. 1984, Pastuszewska et al. 2000b, Dongowski et al. 2002) and pectin-fed hamsters (Trautwein et al. 1998). This phenomenon seems be related to an increased metabolic activity of cecal microorganisms as was also observed in rats fed lactulose (a disaccharide indigestible in the small intestine) and inulin (Zduńczyk et al. 2004). Amidation of pectin changed the cecal fermentation pattern. The most pronounced effect was a significant decrease in the total SCFA concentration and reduction of acetate molar proportion. In our previous study, the production of SCFA and fermentation gas in cultures of the colonic contents of pigs supplied with amidated pectins correlated negatively with the degree of 
Table 5. Effect of pectin and amidated pectins on composition of feces of rats fed a high-cholesterol diet

\begin{tabular}{|c|c|c|c|c|c|c|}
\hline & \multicolumn{3}{|c|}{ Experiment I } & \multicolumn{3}{|c|}{ Experiment II } \\
\hline & Control & Pectin & $\begin{array}{c}\text { Pectinamide } \\
(30 \%)\end{array}$ & Control & Pectin & $\begin{array}{c}\text { Pectinamid } \\
\text { e }(53 \%)\end{array}$ \\
\hline Dry matter (\%) & $57.4 \pm 4.5$ & $54.2 \pm 3.7$ & $59.7 \pm 3.4$ & $59.8 \pm 3.7$ & $54.3 \pm 5.5$ & $57.3 \pm 3.5$ \\
\hline Fat $(m g / g)$ & $84.0 \pm 13.0$ & $71.7 \pm 12.8$ & $88.1 \pm 7.9$ & $93.2 \pm 6.8$ & $70.8 \pm 9.3$ & $107.5 \pm 31.7^{\#}$ \\
\hline $\begin{array}{l}\text { Cholesterol } \\
(\mu \mathrm{mol} / \mathrm{g})\end{array}$ & $18.5 \pm 4.9$ & $19.3 \pm 2.8$ & $31.8 \pm 2.9{ }^{* \#}$ & $17.3 \pm 2.7$ & $14.7 \pm 1.3$ & $28.0 \pm 2.9 * \#$ \\
\hline $\begin{array}{l}\text { Coprostanol } \\
(\mu \mathrm{mol} / \mathrm{g})\end{array}$ & $9.5 \pm 2.3$ & $8.7 \pm 2.0$ & $2.4 \pm 0.4 * \#$ & $9.8 \pm 2.7$ & $8.2 \pm 2.5$ & $3.7 \pm 1.5 * \#$ \\
\hline \multicolumn{7}{|c|}{ Fecal metabolites } \\
\hline $\begin{array}{l}\text { Total SCFA } \\
(\mu \mathrm{mol} / \mathrm{g})\end{array}$ & $182.8 \pm 14.0$ & $182.6 \pm 21.4$ & $145.1 \pm 12.4^{* \#}$ & $177.8 \pm 21.6^{\mathrm{a}}$ & $161.4 \pm 23.6$ & $132.5 \pm 23.1 *$ \\
\hline $\begin{array}{l}\text { Acetate } \\
(\mathrm{mol} . \%)\end{array}$ & $67.2 \pm 1.6$ & $64.5 \pm 2.7$ & $63.5 \pm 2.1 *$ & $73.2 \pm 3.6$ & $72.3 \pm 3.3$ & $70.3 \pm 2.0$ \\
\hline $\begin{array}{l}\text { Propionate } \\
\text { (mol. \%) }\end{array}$ & $10.6 \pm 0.6$ & $10.2 \pm 0.7$ & $9.5 \pm 0.7 *$ & $9.9 \pm 1.1$ & $10.2 \pm 1.2$ & $10.1 \pm 0.5$ \\
\hline $\begin{array}{l}\text { Butyrate } \\
\text { (mol. \%) }\end{array}$ & $12.0 \pm 1.2$ & $13.8 \pm 2.7$ & $16.7 \pm 3.4 *$ & $13.3 \pm 2.6$ & $12.9 \pm 2.4$ & $14.6 \pm 1.4$ \\
\hline $\begin{array}{l}\text { Other SCFA } \\
\text { (mol. \%) }\end{array}$ & $10.2 \pm 1.2$ & $11.5 \pm 1.4$ & $10.3 \pm 2.2$ & $3.6 \pm 0.6$ & $4.6 \pm 1.1$ & $5.0 \pm 0.7 *$ \\
\hline $\begin{array}{l}\text { Ammonia } \\
(\mu \mathrm{mol} / \mathrm{g})\end{array}$ & $28.4 \pm 5.0$ & $27.2 \pm 6.0$ & $27.2 \pm 6.0$ & $25.4 \pm 7.2$ & $37.6 \pm 12.8$ & $28.6 \pm 11.3$ \\
\hline
\end{tabular}

Data are mean values \pm S.D. Significant differences $(p<0.05): *$ from controls, ${ }^{*}$ from pectin.

amidation. Amidation of pectin at 30 and $53 \%$ decreased its fermentability to one half and one fifth, respectively (Marounek et al. 2005). In feces, total SCFA concentrations were higher than in the cecal content. A possible explanation is that in the colon water was absorbed more easily than SCFA. Butyrate, which is the primary respiratory fuel for colonocytes, was absorbed in the colon to a greater extent than other SCFA. Its molar percentage in fecal SCFA was twofold lower than in cecal SCFA, whereas molar percentage of acetate increased and that of propionate was similar in cecal and fecal samples. Molar proportion of butyrate in all cecal and fecal samples exceeded that of propionate. According to Mathers et al. (1993) increased cecal butyrate has been associated with greater flow of fermentable material to the large bowel and reduced transit time of cecal digesta. In other reports, however, the molar quantity of butyrate was lower than that of propionate (Pastuszewska et al. 2000b, Dongowski et al. 2002, Zduńczyk et al. 2004). Amidation of pectin did not influence the cecal ammonia concentration. Cecal ammonia concentration depends on the rate of ammonia production in deamination reactions and ammonia utilization by cecal microorganisms.

Several authors reported that dietary pectin increased the activity of 3-hydroxymethyl-3-glutaryl CoA reductase (Hexeberg et al. 1994, Moundras et al. 1994, Garcia-Diez et al. 1996, Park et al. 2000) and cholesterol 7a-hydroxylase (Moundras et al. 1994, Matheson et al. 1995, Garcia-Diez et al. 1996, Fernandez et al. 1999), which are the regulatory enzymes of cholesterol and bile acids biosynthesis, respectively. This suggests that the effect of pectin and other soluble fibers on cholesterol metabolism may be modulated through an increased hepatic pool of cholesterol (Basu et al. 1993) and bile acids (Matheson et al. 1995). Increased excretion of neutral and acid sterols, however, is thought to be the major determinant for the cholesterol-lowering effect of pectin. Pectin used in this study increased cecum weight and marginally influenced cecal metabolites, but had no effect on cholesterol homeostasis. The reasons for this are not clear, but some other authors have also reported the absence of significant cholesterol-lowering effects of pectin (Vonderheyde et al. 1993, Trautwein et al. 1998, Yamada et al. 2003). Structural and physico-chemical 
characteristics of pectin such as molecular weight, degree of methylation and viscosity of its solution are factors which may influence fecal cholesterol and bile acid excretion. On the other hand, amidated derivatives of the same pectin significantly modified cholesterol metabolism and decreased hepatic concentration of fat. The effects of a more amidated pectin were more pronounced.

\section{Acknowledgements}

This study was supported by the Ministry of Agriculture of the Czech Republic (project No. MZE0002701403), Czech Science Foundation (project No. 525/03/0358), and Academy of Sciences of the Czech Republic (project No. AVOZ 50450515).

\section{References}

ARJMANDI BH, CRAIG J, NATHANI S, REEVES RD: Soluble dietary fiber and cholesterol influence in vivo hepatic and intestinal cholesterol-biosynthesis in rats. J Nutr 122: 1559-1565, 1992.

ASPINALL GO: Polysaccharides. Pergamon Press, Oxford, 1970.

BASU TK, OORAIKUL B, GARG ML: Effects of dietary pectin on the hepatic activities of hydroxymethyl glutaryl CoA reductase and acyl CoA cholesterol acyltransferase in cholesterol supplemented mice. J Nutr Biochem 4: 472-475, 1993.

BOURQUIN LD, TITGEMEYER EC, FAHEY GC: Fermentation of various dietary fiber by human fecal bacteria. Nutr Res 16: 1119-1131, 1996.

CARR TP, WOOD KJ, HASSEL CA, BAHL R, GALLAHER DD: Raising intestinal contents viscosity leads to greater excretion of neutral sterols but not bile acids in hamsters and rats. Nutr Res 23: 91-102, 2003.

CONWAY EJ: Microdiffusion Analysis and Volumetric Error. Crosby Lockwood, London, 1957.

DONGOWSKI G, LORENZ A, PROLL J: The degree of methylation influences the degradation of pectin in the intestinal tract of rats and in vitro. J Nutr 132: 1935-1944, 2002.

EBIHARA K, MIYADA T, NAKAJIMA A: Comparison of propionic acid and sodium propionate infused to the cecum and stomach on hypocholesterolemic effect in rats fed a cholesterol-free, casein protein diet. Nutr Res 13: 1305-1311, 1993.

FERNANDEZ ML: Distinct mechanisms of plasma LDL lowering by dietary fiber in the guinea-pig-specific effects of pectin, guar gum, and psyllium. J Lipid Res 36: 2394-2404, 1995.

FERNANDEZ ML, SUN DM, TOSCA MA, MCNAMARA DJ: Citrus pectin and cholesterol interact to regulate hepatic cholesterol homeostasis and lipoprotein metabolism - a dose-response study in guinea pigs. Am J Clin Nutr 59: 869-878, 1994.

FERNANDEZ ML, WILSON TA, CONDE K, VERGARA-JIMENEZ M, NICOLOSI RJ: Hamsters and guinea pigs differ in their plasma lipoprotein cholesterol distribution when fed diets varying in animal protein, soluble fiber, or cholesterol content. J Nutr 129: 1323-1332, 1999.

FOLCH JM, LEES M, SLOANE-STANLEY GH: A simple method for the isolation and purification of total lipids from animal tissues. J Biol Chem 226: 497-509, 1957.

GALLAHER CM, MUNION J, HESSLINK R JR, WISE J, GALLAHER DD: Cholesterol reduction by glucomannan and chitosan is mediated by changes in cholesterol absorption and bile acid and fat excretion in rats. J Nutr 130: 2753-2759, 2000.

GARCIA-DIEZ F, GARCIA-MEDIAVILLA V, BAYON JE, GONZALES-GALLEGO J: Pectin influences fecal bile acid excretion, hepatic bile acid and cholesterol synthesis and serum cholesterol in rats. J Nutr 126: 1766-1771, 1996.

HAN K-H, FUKUSHIMA M, SHIMIZU K, KOJIMA M, OHBA K, TANAKA A, SHIMADA K, SEIKAWA M, NAKANO M: Resistant starches of beans reduce the serum cholesterol concentration in rats. $J$ Nutr Sci Vitaminol 49: 281-286, 2003.

HEXEBERG S, HEXEBERG E, WILLUMSEN N, BERGE RK: A study on lipid-metabolism in heart and liver of cholesterol-fed and pectin-fed rats. Br J Nutr 71: 181-192, 1994.

HORTON JD, CUTHBERT JA, SPADY DK: Regulation of hepatic $7 \alpha$-hydroxylase expression and response to dietary cholesterol in the rat and hamster. J Biol Chem 270: 5381-5387, 1995. 
ISO 3596-1: Animal and vegetable fats and oils. Determination of unsaponifiable matter. Part 1: Method using diethyl ether extraction. Czech Standards Institute, Prague, 1988.

JUDD PA, TRUSWELL AS: The hypocholesterolaemic effects of pectins in rats. Br J Nutr 53: 409-425, 1985.

MAROUNEK M, SYNYTSYA A, ČOPÍKOVÁ J, SIROTEK K: Assay of availability of amidated pectins for colonic microorganisms (in Czech). Chem Listy 99: 591-593, 2005.

MATHERS JC, KENNARD J, JAMES OFW: Gastrointestinal responses to oats consumption in young adult and elderly rats: digestion, large bowel fermentation and crypt cell proliferation rates. Br J Nutr 70: 567-584, 1993.

MATHESON HB, COLON IS, STORY JA: Cholesterol 7-alpha-hydroxylase activity is increased by dietary modification with psyllium hydrocolloid, pectin, cholesterol and cholestyramine in rats. $J$ Nutr 125: 454-458, 1995.

MOSENTHIN R, SAUER WC, AHRENS F: Dietary pectin's effect on ileal and fecal amino acid digestibility and exocrine pancreatic secretions in growing pigs. J Nutr 124: 1222-1229, 1994.

MOUNDRAS C, BEHR SR, DEMIGNE C, MAZUR A, REMESY C: Fermentable polysaccharides that enhance fecal bile-acid excretion lower plasma-cholesterol and apolipoprotein E-rich HDL in rats. $J$ Nutr 124: 2179-2188, 1994.

PARK HS, CHOI JS, KIM KH: Docosahexaenoic acid-rich fish oil and pectin have a hypolipidemic effect, but pectin increases risk factor for colon cancer in rats. Nutr Res 20: 1783-1794, 2000.

PASTUSZEWSKA B, KOWALCZYK J, OCHTABIŃSKA A: Dietary carbohydrates affect caecal fermentation and modify nitrogen excretion patterns in rats I. Studies with protein-free diets. Arch Anim Nutr 53: 207-225, 2000a.

PASTUSZEWSKA B, KOWALCZYK J, OCHTABIŃSKA A: Dietary carbohydrates affect caecal fermentation and modify nitrogen excretion patterns in rats II. Studies with diets differing in protein quality. Arch Anim Nutr 53: 335-352, 2000b.

PEARSE AGE: Histochemistry Theoretical and Applied, Vol. 1. J \& A Churchill Ltd., London, 1968.

SAITO D, NAKAJI S, FUKUDA S, SHIMOYAMA T, SAKAMOTO J, SUGAWARA K: Comparison of the amount of pectin in the human terminal ileum with the amount of orally administered pectin. Nutrition 21: 914-919, 2005.

SYNYTSYA A, ČOPÍKOVÁ J, MAROUNEK M, MLČOCHOVÁ P, SIHELNÍKOVÁ L, SKOBLYA S, HAVLÁTOVÁ H, MATĚJKA P, MARYŠKA M, MACHOVIČ V: N-octadecyl pectinamide, a hydrophobic sorbent based on modification of highly methoxylated citrus pectin. Carbohyd Polym 56: 169-179, 2004.

SYNYTSYA A, ČOPÍKOVÁ J, FESSLOVÁ L, SIHELNÍKOVÁ L: Sorption of bile acids on N-alkylpectinamides. In: Proceedings of the First Czech Conference on Structure and Biological Effects of Polysaccharides and Their Derivatives (CD-ROM). Institute of Chemical Technology in Prague, Czech Republic, 2005.

TERPSTRA AHM, LAPRE JA, DE VRIES HT, BEYNEN AC: Dietary pectin with high viscosity lowers plasma and liver cholesterol concentration and plasma cholesteryl ester transfer protein activity in hamsters. $J$ Nutr $\mathbf{1 2 8}$ : 1944-1949, 1998.

TERPSTRA AHM, LAPRE JA, DE VRIES HT, BEYNEN AC: The hypocholesterolemic effect of lemon peels, lemon pectin, and the waste stream material of lemon peels in hybrid F1B hamsters. Eur J Nutr 41: 19-26, 2002.

THAKUR BR, SLUGH RK, HANDA AK: Chemistry and uses of pectin - a review. Crit Rev Food Sci 37: 47-73, 1997.

THOMSEN LL, ROBERTON AM, WONG J, LEE SP, TASMAN-JONES C: Intra-caecal short chain fatty acids are altered by dietary pectin in rats. Digestion 29: 129-137, 1984.

TRAUTWEIN EA, RIECKHOFF D, KUNATH-RAU A, ERBERSDOBLER HF: Psyllium, not pectin or guar gum, alters lipoprotein and biliary bile acid composition and fecal sterol excretion in the hamster. Lipids 33: 573$582,1998$.

VAN BENNEKUM AM, NGUYEN DV, SCHULTHESS G, HAUSER H, PHILLIPS MC: Mechanisms of cholesterollowering effects of dietary insoluble fibres: relationships with intestinal and hepatic cholesterol parameters. Br J Nutr 94: 331-337, 2005.

VONDERHEYDE R, VONDERHEYDE MED, WOSIACKI G: Relationship between dietary fiber, serum lipids and fecal excretion of biliary acids. An experimental study with rats. Arch Biol Technol 36: 207-218, 1993. 
WAKERLY Z, FELL J, ATTWOOD D, PARKINS D: Studies on amidated pectins as potential carriers in colonic drug delivery. J Pharm Pharmacol 49: 622-625, 1997.

WOLFORD ST, SCHROER RA, GOHS FX, GALLO PP, BRODECK M, FALK HB, RUHREN R: Reference range data base for serum chemistry and hematology values in laboratory animals. $J$ Toxicol Env Health 18: 161-188, 1986.

YAMADA K, TOKUNAGA Y, IKEDA A, OHKURA K, KAKU-OHKURA S, MAMIYA S, LIM BO, TACHIBANA $\mathrm{H}$ : Effect of dietary fiber on the lipid metabolism and immune function of aged Sprague-Dawley rats. Biosci Biotechnol Biochem 67: 429-433, 2003.

ZDUŃCZYK Z, JUŚKIEWICZ J, WRÓBLEWSKA M, KRÓL B: Physiological effects of lactulose and inulin in the cecum of rats. Arch Anim Nutr 58: 89-98, 2004.

\section{Corresponding author}

M. Marounek, Institute of Animal Physiology and Genetics, Academy of Sciences of the Czech Republic, Vídeňská 1083, CZ-142 20 Prague 4, Czech Republic. E-mail: marounek@iapg.cas.cz 